\title{
PROFIL KADAR MALONDIALDEHIDA, GLUKOSA DAN KOLESTEROL PADA TIKUS PUTIH YANG TERPAPAR ASAP ROKOK
}

\author{
Lizma Febrina*, Helmi, Laode Rijai \\ Laboratorium Penelitian dan Pengembangan FARMAKA TROPIS \\ Fakultas Farmasi Universitas Mulawarman, Samarinda, Kalimantan Timur \\ Email:lizma@farmasi.unmul.ac.id
}

\begin{abstract}
ABSTRAK
Asap rokok merupakan salah satu sumber radikal bebas eksogen yang dapat melemahkan pertahanan antioksidan sehingga kadar radikal bebas dalam tubuh meningkat. Peningkatan kadar radikal mempercepat kerusakan sel sehingga mengganggu metabolisme di dalam tubuh. Penelitian ini bertujuan untuk mengetahui apakah radikal bebas dari asap rokok dapat mempengaruhi kadar glukosa dan kolesterol pada hewan coba. Tikus wistar jantan dengan berat \pm 200 gram dipergunakan sebagai hewan coba dan dipaparkan asap rokok sebanyak 1 batang setiap pagi dan sore. Setelah tujuh hari, semua tikus diambil darahnya untuk analisis MDA, glukosa dan kolesterol. MDA dianalisis menggunakan metode TBARS (Thiobarbituric Acid Reactive Substance )yang diukur dengan spektrofotometer UV-Vis pada $\chi=531 \mathrm{~nm}$, sedangkan glukosa dan kolesterol diukur menggunakan test strip. Hasil yang didapat kadar MDA meningkat 6x lipat setelah dipaparkan asap rokok, disertai kenaikan glukosa sebanyak 1,5x lipat sementara kolesterol menurun $0,25 \mathrm{x}$ lipat dibandingkan sebelum dipaparkan.
\end{abstract}

Kata Kunci : Malondialdehida, glukosa, kolesterol

\begin{abstract}
Cigarette smoke is one of the potential of exogenous free radicals which can weaken antioxidant system so that can increase free radicals levels in the body. The increasing of free radicals can accelerating damage to cells that interfere with the metabolism in the body. This study aimed to determine whether free radicals from cigarette smoke can affect glucose and cholesterol levels in experimental animals. This research used male-2-old-month-rats that have weigth \pm 200 grams and exposed to cigarette smoke as much as 1 stick every morning and afternoon for 7 days. The MDA levels was analyzed with Thiobarbituric Acid Reactive Substance (TBARS) method by spectrophotometer UV-Vis in $\chi=531 \mathrm{~nm}$, whereas glucose and cholesterol were measured using a test strip. The results of MDA increased 6x first level after exposed to cigarette smoke, glucose level increase 1,5x frist level and cholesterol deacrease $0,25 \mathrm{x}$ after exposed to cigarette smoke.
\end{abstract}

Keywords: Malondialdehyde glucosa, cholesterol 


\section{PENDAHULUAN}

Bahaya rokok bukan saja menghantui mereka yang menjadi perokok aktif, namun merambah kepada para perokok pasif. Kemungkinan perokok pasif untuk mengalami gangguan kesehatan akibat asap rokok yang dihirup mencapai 30\% (Barber, 2008). Asap rokok terdiri atas campuran substansisubstansi kimia dalam bentuk gas dan partikel-partikel terdispersi di dalamnya. Sampai saat ini, telah berhasil diisolasi beragam zat kimia yang jumlahnya mencapai 4000 senyawa dalam asap rokok (Benowitz dan Fu, 2007). Sebagian besar bahan atau senyawa tersebut bersifat toksik dalam bentuk gas, yaitu berupa karbon monoksida (CO), hidrogen sianida $(\mathrm{HCN})$, dan oksida nitrogen (NO), sedangkan substansi toksik dalam bentuk zat kimia volatile yaitu nitrosamine dan formaldehida. Oksidan dalam rokok terutama oksida nitrogen (NO) akan menurunkan jumlah antioksidan intraseluler dan memainkan peran yang besar dalam penghasilan radikal $\mathrm{O}^{*}, \mathrm{H}_{2} \mathrm{O}_{2}$ dan HO*.

$\begin{array}{ccc}\text { Dilihat dari zat yang } & \text { dapat } \\ \text { dikandungnya, } & \text { merokok } & \text { dapas }\end{array}$ meningkatkan level radikal bebas di dalam tubuh. Radikal bebas bersifat dekstruktif, sangat reaktif dan mampu bereaksi dengan makromolekul dalam tubuh, salah satunya dengan lipid (fosfolipid) pada membran sel. Lipid merupakan salah satu molekul yang paling sensitif terhadap serangan radikal bebas sehingga terbentuk lipid peroksida yang selanjutnya akan dihasilkan malondialdehida. Senyawa ini dijadikan biomarker kadar radikal bebas di dalam tubuh. Konsentrasi MDA yang tinggi menunjukkan jumlah radikal bebas yang tinggi pula di dalam tubuh.

Meningkatnya kadar MDA di dalam tubuh menggambarkan kerusakan sel, dalam hal ini diawali oleh rusaknya membran sel, sehingga akan mengakibatkan terganggunya proses metabolisme di dalam tubuh. Telah banyak penelitian yang menghubungkan antara aktivitas radikal bebas dapat memicu kerusakan DNA (Fitria dkk.,2013), serta memicu timbulnya penyakit degeneratif pada beberapa sistem organ, yaitu sistem pernapasan, sistem gastroinstestinal, kulit, sistem saraf dan sistem imun (Burns 2005, Tyndale dan Sellers 2005, Hukkanen dkk 2005, McPhee dan Pignone 2007). Kerusakan tersebut disebabkan oleh serangkaian mekanisme yaitu reaksi oksidasi, adisi, subtitusi dan reduksi antara radikal bebas dengan molekul biologis.

Oleh karena sifat reaksi dari radikal bebas yang acak (random), maka penelitian ini bertujuan untuk melihat apakah paparan radikal bebas dari asap rokok dapat mempengaruhi metabolisme glukosa serta kadar kolesterol dalam tubuh.

\section{METODE PENELITIAN}

\begin{abstract}
Alat
Seperangkat alat kaca, chamber induksi, gunting bedah, holder, mikropipet, hot plate, sentrifuge, spektrofotometri UV-Vis, timbangan analitik, timbangan hewan, glukometer, strip glukosa dan kolesterol.
\end{abstract}

\section{Bahan}

Asam asetat glasial, aquadest., Asam klorida, asam tiobarbiturat (TBA), asam trikloro asetat (TCA), etanol 70\%, etilen diamin tetra asetat (EDTA), kapas,dan tetra metoksi propana (TMP).

\section{Prosedur}

\section{Persiapan Hewan Coba}

Disiapkan hewan coba, yakni tikus putih sehat dengan anggota tubuh yang lengkap dan normal. Kemudian 
dikelompokkan menjadi 2 kelompok yang berbeda, yakni kelompok kontrol dan kelompok eksperimen, masing-masing kelompok berjumlah 5 ekor. Diberikan pakan standar, berupa pellet dan minuman standar, berupa air minum secara rutin dan teratur serta diperhatikan kebersihan kandang serta penggantian sekam setiap 2 hari sekali. Hewan coba tidak diberikan perlakuan uji pada minggu pertama sebagai waktu untuk beradaptasi di lingkungan yang baru.

\section{Persiapan Bahan Uji}

Disiapkan bahan uji, berupa asap dari rokok jenis rokok filter.

\section{Pemaparan Bahan Uji}

Dimasukkan hewan coba dalam chamber induksi yang berukuran38,5 $\times$ $28,5 \times 22,5 \mathrm{~cm}$ lengkap dengan ventilasi udara, dialirkan asap yang telah dikumpulkan dalam chamber pengumpul asap hingga asap habis. Proses pemaparan dilakukan setiap pagi dan sore hari dengan menggunakan asap dari 1 batang rokok selama 7 hari.

\section{Pengambilan Plasma Darah}

Dimasukkan hewan coba ke dalam holder untuk mempermudah proses pengambilan darah melalui ekor, Diusap bagian ekor tikus dengan kapas yang telah dibasahi dengan etanol 70\%, lalu dipotong sedikit ujung ekor tikus. Diusap secara perlahan dari pangkal hingga ujung ekor, ditampung $1 \mathrm{~mL}$ darah yang keluar dan dikumpulkan dalam tabung reaksi yang telah berisi EDTA $1 \mathrm{~mL}$. Disentrifugasi darah yang telah ditampung dalam tabung reaksi pada tahap sebelumnya dengan kecepatan 3000 rpm selama 15 menit. Diambil supernatan untuk pengujian tahap selanjutnya. Plasma darah hewan coba diambil sebelum dan setelah pemaparan.

\section{Pembuatan Kurva Baku Tetra Metoksi Propan (TMP)}

Dibuat larutan TMP dengan konsentrasi $20 \mathrm{nmol} / \mathrm{mL}$ sebagai standar dalam pengujian kadar MDA sampel. Diambil dari larutan stok tersebut sebanyak 0,$65 ; 1,25 ; 2,5 ; 5$ dan 10 ppm. Lalu dimasukkan $0,5 \mathrm{~mL}$ ke dalam 5 buah tabung reaksi yang berbeda. Ditambahkan Asam Trikloroasetat (TCA) 20\% sebanyak $1 \mathrm{~mL}$ ke dalam setiap tabung reaksi, lalu dikocok hingga homogen. Ditambahkan Aquadest ke dalam setiap tabung reaksi hingga volumenya mencapai $2 \mathrm{~mL}$. Ditambahkan reagen Asam Tiobarbiturat (TBA) $0,67 \%$ sebanyak $1 \mathrm{~mL}$ ke dalam setiap tabung reaksi, dikocok kembali hingga homogen. Digunakan larutan yang sama tanpa TMP sebagai blanko. Dimasukkan semua tabung reaksi ke dalam pemanas air pada suhu $100^{\circ}{ }^{\circ} \mathrm{C}$ selama 10 menit, lalu didinginkan. Diukur absorbansi pada $\chi=$ $531 \mathrm{~nm}$ dengan menggunakan spektrofotometer UV-Visibel dan dibuat kurva kalibrasi.

\section{Pengukuran Kadar MDA Sampel}

Dipipet $1 \mathrm{~mL}$ supernatan (plasma) dari semua kelompok, baik kelompok uji maupun kontrol ke dalam tabung reaksi. Ditambahkan TCA 20\% sebanyak $1 \mathrm{~mL}$. Disentrifugasi dengan kecepatan $3000 \mathrm{rpm}$ selama 5 menit. Dipipet $1 \mathrm{~mL}$ supernatan dan ditambahkan dengan $1 \mathrm{~mL}$ TBA $0,67 \%$. Diukur absorbansi dari warna yang terbentuk pada $\chi=531 \mathrm{~nm}$ dengan menggunakan spektrofotometer UV-Visibel. Dihitung kadar MDA sampel dengan menggunakan kurva kalibrasi dari TMP.

\section{Pengukuran Kadar Glukosa dan Kolesterol}

Pengukuran kadar glukosa dan kolesterol dilakukan dengan alat test strip. Pengujian ini dilakukan pada semua kelompok hewan coba dan dilakukan sebelum dan setelah pemaparan. 


\section{HASIL DAN PEMBAHASAN}

Sumber radikal bebas yang digunakan berasal dari 1 batang asap rokok setiap pagi dan sore hari selama 7 hari pemaparan. Digunakan 1 batang, dikarenakan ini adalah jumlah terkecil seorang perokok untuk merokok setiap harinya.

Pengukuran kadar MDA dalam penelitian ini menggunakan metode Thiobarbituric Acid Reactive Substances (TBARS) dimana 2 molekul asam tiobarbiturat (TBA) akan bereaksi dengan 2 gugus karbonil dari 1 molekul MDA, sehingga akan terbentuk suatu senyawa kompleks MDA-TBA 2 yang berwana sehingga dapat terukur menggunakan spektrofotometer UV-Vis.

Adapun baku yang digunakan adalah TMP atau 1,1,3,3 Tetrametoksipropana atau malondialdehid bis. TMP digunakan sebagai standar dalam pengujian ini dikarenakan sulitnya memproduksi senyawa malondialdehid (MDA) murni yang stabil selama penyimpanan, sehingga MDA dapat diperoleh melalui hidrolisis TMP dengan pemanasan dalam suasana asam dengan metanol sebagai hasil samping reaksi.
Suasana panas dan asam digunakan untuk mempercepat proses hidrolisis yang dilakukan oleh air terhadap TMP, dimana 2 buah gugus metoksi $\left(-\mathrm{OCH}_{3}\right)$ dari TMP akan terputus dan bereaksi dengan $\mathrm{H}^{+}$dari $\mathrm{H}_{2} \mathrm{O}$, sehingga terbentuk 2 molekul metanol $\left(\mathrm{CH}_{3} \mathrm{OH}\right)$, begitu pula dengan 2 buah gugus metil $\left(-\mathrm{CH}_{3}\right)$ dari TMP juga akan terputus dan bereaksi dengan $\mathrm{OH}^{-}$ dari $\mathrm{H}_{2} \mathrm{O}$ dan membentuk 2 molekul metanol $\left(\mathrm{CH}_{3} \mathrm{OH}\right)$. Adapun atom oksigen yang kelebihan elektron dan atom karbon yang kekurangan elektron, akibat putusnya gugus metoksi dan metil tadi akan mengalami penataan ulang elektron dan membentuk ikatan karbonil $(\mathrm{C}=\mathrm{O})$ hingga terbentuk senyawa aldehid, yang disebut MDA, sehingga hidrolisis 1 molekul TMP akan menghasilkan 1 molekul MDA dan 4 molekul metanol (Gambar 1).

Analisis kadar MDA dilakukan dengan menggunakan serum darah tikus yang diukur menggunakan spektrofotometer, sedangkan kadar glukosa dan kolesterol dijuji menggunakan test strip. Hasil pengukuran ditunjukkan pada Tabel 1.<smiles>COC(CC(OC)OC)OC</smiles>

Gambar 1. Reaksi Pembentukan MDA dari TMP

Tabel 1. Kadar MDA, glukosa dan kolesterol hewan uji

\begin{tabular}{|c|c|c|c|c|c|c|}
\hline \multirow{3}{*}{$\begin{array}{l}\text { Kelompok } \\
\text { Perlakuan }\end{array}$} & \multicolumn{6}{|c|}{ Rerata Pengukuran } \\
\hline & \multicolumn{2}{|c|}{ Kadar MDA } & \multicolumn{2}{|c|}{ Glukosa } & \multicolumn{2}{|c|}{ Kolesterol } \\
\hline & Awal & Hari ke-7 & Awal & Hari ke-7 & Awal & Hari ke-7 \\
\hline Kontrol & 1,05 & 2,38 & 74 & 93 & 157 & 163 \\
\hline Asap Rokok & 0,36 & 2,32 & 66 & 98 & 205 & 153 \\
\hline
\end{tabular}


Tabel 2. Perubahan Kadar MDA, glukosa dan kolesterol hewan uji

\begin{tabular}{cllllll}
\hline Kelompok & \multicolumn{5}{c}{ Perubahan Kadar } \\
\cline { 2 - 6 } Perlakuan & \multicolumn{2}{c}{ MDA } & \multicolumn{2}{c}{ Glukosa } & \multicolumn{1}{c}{ Kolesterol } \\
\hline Kontrol & $\begin{array}{l}\text { Meningkat } \\
\text { kadar awal }\end{array}$ & 2x & dari & $\begin{array}{l}\text { Meningkat 1,3x } \\
\text { dari kadar awal }\end{array}$ & $\begin{array}{l}\text { Meningkat 1x dari } \\
\text { kadar awal }\end{array}$ \\
Asap Rokok & $\begin{array}{l}\text { Meningkat } \\
\text { kadar awal }\end{array}$ & $6 \mathrm{x}$ & dari & $\begin{array}{l}\text { Meningkat 1,5x } \\
\text { dari kadar awal }\end{array}$ & $\begin{array}{l}\text { Menurun 0,25x } \\
\text { dari kadar awal }\end{array}$ \\
\hline
\end{tabular}

MDA dihasilkan dari adanya oksidasi terhadap asam lemak tak jenuh oleh radikal bebas di dalam tubuh. MDA hanya akan dibentuk oleh asam lemak dengan 3 atau lebih ikatan rangkap dan digunakan sebagai ukuran peroksidasi lipid. Peroksidasi (autooksidasi) lipid merupakan suatu proses yang terjadi, ketika radikal peroksil akan menyerang ikatan rangkap pada lipid sehingga akan terjadi serangkaian proses kompleks yang dikenal dengan istilah inisiasi, propagasi dan terminasi hingga dihasilkan molekulmolekul reaktif yang sifatnya membahayakan bagi tubuh, diantaranya MDA, 4-hidroksinonenal (HNE), isoprostan dan berbagai senyawa lainnya. Dimana MDA merupakan produk peroksidasi lipid terbesar dibandingkan dengan senyawa-senyawa lainnya, yakni berkisar $80-82 \%$ atau kadarnya 10 kali lebih besar dibandingkan kadar senyawa lain yang juga dihasilkan, oleh karena itu MDA sering digunakan sebagai biomarker adanya radikal bebas dalam tubuh.

Berdasarkan data yang diperoleh terlihat bahwa sebelum adanya perlakuan pada hewan coba, telah terbentuk MDA di dalam tubuh, namun masih dalam kadar yang relatif rendah. Hal ini sesuai dengan teori yang mengatakan bahwa dalam keadaan normal tubuh akan tetap memproduksi radikal bebas dalam jumlah tertentu sebagai hasil samping dari reaksi pernafasan, metabolisme dan berbagai mekanisme endogen tubuh lainnya. Senyawa radikal tersebut diproduksi di dalam sel oleh mitokondria, membran plasma, lisosom, peroksisom, retikulum endoplasma dan inti sel. Keberadaan radikal-radikal ini tetap akan bereaksi dengan lipid membran tubuh, karena lipid merupakan komponen utama penyusun sel yang kaya akan ikatan rangkap, sehingga lipid merupakan target utama senyawa radikal bebas, namun masih dapat dinetralisir oleh antioksidan endogen tubuh. Sehingga kadar MDA tetap terbentuk, namun masih di dalam rentang yang wajar.

Dari data terlihat bahwa terjadi peningkatan kadar MDA semua kelompok hewan coba pada hari ke-7, baik kelompok kontrol dan kelompok asap rokok yakni sebagai berikut kadar MDA kontrol meningkat dari $1,05 \mathrm{nmol} / \mathrm{mL}$ menjadi $2,38 \mathrm{nmol} / \mathrm{mL}$ atau meningkat $2 \times$ kadar awal. Kadar MDA kelompok asap rokok meningkat dari $0,36 \mathrm{nmol} / \mathrm{mL}$ menjadi $2,32 \mathrm{nmol} / \mathrm{mL}$ atau meningkat $6 \times$ kadar awal. Hal ini membuktikan bahwa, peningkatan kadar MDA tetap terjadi pada kelompok kontrol seiring dengan jumlah radikal bebas yang terus diproduksi oleh tubuh, namun peningkatan yang terjadi tidak signifikan karena secara normal tubuh masih mampu mengatasinya, sedangkan pada kelompok asap rokok kadar MDA meningkat secara signifikan. Hal ini memperlihatkan bahwa asap rokok mampu meningkatkan jumlah radikal bebas dalam tubuh.

Kelompok asap rokok merupakan kelompok dengan peningkatan kadar glukosa tertinggi dibandingkan dengan kelompok hewan coba lainnya, yakni dengan peningkatan sebesar $1,5 \times$ dan hal ini kembali memperlihatkan adanya korelasi antara peningkatan kadar glukosa dengan peningkatan kadar MDA 
di dalam tubuh hewan coba. Peningkatan kadar glukosa darah merupakan salah satu tanda awal terjadinya gangguan dalam metabolisme karbohidrat. Metabolisme karbohidrat dipengaruhi oleh kerja insulin. Insulin menjaga keseimbangan glukosa dalam darah dan bertindak meningkatkan pengambilan glukosa oleh sel tubuh untuk diubah menjadi energi. Kegagalan tubuh untuk menghasilkan insulin atau jumlah insulin yang tidak mencukupi akan menyebabkan glukosa tidak dapat masuk ke dalam sel untuk proses metabolisme, sehingga glukosa di dalam darah meningkat dan menyebabkan diabetes mellitus. Walaupun demikian, mekanisme kerja radikal bebas dalam mengganggu metabolisme glukosa masih perlu dikaji lebih lanjut.

Pada kelompok kontrol kadar kolesterol terus meningkat dari awal hingga akhir pengujian, hal ini membuktikan bahwa hewan coba tidak mengalami stres oksidatif yang berarti. Hal ini sesuai, karena kelompok kontrol tidak dipaparkan bahan uji. Peningkatan kadar kolesterol selama pengujian, disebabkan karena hewan tetap mendapatkan pakan standar setiap harinya, dimana lemak merupakan salah satu kandungan dalam pakan tersebut.

Berbeda dengan kelompok perlakuan, kadar kolesterol mengalami penurunan setelah hari ke-7. Penurunan kadar kolestreol yang terjadi akibat adanya radikal bebas di dalam tubuh, bukanlah hal yang baik. Hal ini dikarenakan terjadinya reaksi antara radikal bebas dengan kolesterol yang dapat dapat memicu terjadinya pembentukan sel-sel busa yang lengket dan proses inflamasi, sehingga berakhir pada pembentukan plak-plak pada dinding pembuluh darah dan dikenal sebagai Atherosklerosis yang merupakan pencetus terjadinya Penyakit Jantung Koroner (PJK).

\section{KESIMPULAN}

Terpapar asap rokok filter 1 batang setiap pagi dan sore hari selama tujuh hari dapat mempengaruhi kadar glukosa dan kolesterol sehingga dapat meningkatkan kemungkinan penyakit diabetes mellitus dan penyakit jantung koroner.

\section{DAFTAR PUSTAKA}

1. Fitria, R.I.N.K Retno Triandhini, Jubhar C. Mangimbulude, Ferry F.Karwur., 2013 Merokok dan Oksidasi DNA., Sains Medika Vol.5, No. 2

2. Hukkanen, J.Jacob P dan Benowitz,N.L.,2005., Metabolism and Disposition Kinetics of Nicotine. The american Society for Pharmacology and Experimental Therapeutics. Vol.57,No.1.

3. McPhee, S.J dan Pignone, M. 2007., Disease Prevention and Health Promotion. In S.J. McPhee, M.A,, Papadakis, \& L.M. Tierney Jr (Eds), Current Medical Diagnosis and Treatment, 47 ${ }^{\text {th }}$ Edition,New York., McGraw-Hill

4. Tyndale, R.F \& Sellers, E. 2005.,Variable CYP2a6 Mediated Nicotine Metabolism Alters Smoking Behavior and Risk. The American Society or Pharmacology and Experimental Therapeutics. Vol. 29 No.4 